\title{
たれ壁・腰壁付架構の一応力計算法
}

\section{たれ壁・腰壁付柱の弾性剛性に関する研究 III}

$\begin{array}{lllll}\text { 正会員 } & \text { 徳 } & \text { 広 } & \text { 育 } & \text { 夫* } \\ \text { 正会員 } & \text { 塩 } & \text { 屋 } & \text { 晋 } & \text { 一** }\end{array}$

\section{1. 序}

はり・柱からなる架構にたれ壁, 腰壁が付設されると 当然のことながら架構の剛性は增加する。これらの壁が 付設された架構の応力計算には, 柱の上下端に剠域を考 慮したラーメン解法が一般に用いられている。この場合, 壁端から剛域までの長さは鉄筋コンクリート構造計算規 準・同解説”に示されている $D / 4(D$ : 柱幅）あるいは 構造計算指針 ${ }^{21}$ に示されている $D / 2$ の值が実際に用いら れている。“剠域の長さは曲げモーメント変化によって 異なるべきであるがそれでは実用にならないので簡単の ため均等曲げモーメントをうけるときの回転角性によっ て代表させ一定のものとする”防と述べてあるように， この $D / 4$ は，はり・柱からなるラーメン材でせん断ス パン比がかなり大きく，かつはり厚と柱厚があまり違わ ない場合を対象として求められた值である。

またたれ壁，腰壁のような柱厚に比べかなり薄い材が 付設された場合の壁上端あるいは壁下端から剛域までの 長さに $D / 4$ を用いると剛性を高く評価しすぎることが すでに指摘されている4)。

著者はこれらの事項を考慮して先に光弾性実験により

a）壁厚と柱厚の比が異なる場合

b）たれ壁腰壁が柱の両側に付く場合と片側に付く場 合

c）せん断スパン比が異なる場合

などの腰壁上端あるいはたれ壁下端から剛域までの長さ およびたれ壁，腰壁が付かない柱（以下独立柱と呼ぶ） に対するせん断力分担割合を定量的に求めた ${ }^{51,6)}$ がその 一例を図一1に示す。腰壁に接する部分を含め全長にわ たって変形している腰壁付柱のせん断力および柱頭柱脚 の相対水平変位と等しい仮想可撓長（材長-変形が生じ ないと仮定した部分すなわち剛域長) の柱の曲げモーメ ントおよび反曲点位置は図一1(c)のようになり, (b) (c) 両者の曲げモーメント分布および材中間での変形は異 なったものとなる。

日本建築学大会学術講演梗概集（同題名，その 1 , その 2 , 昭 和 59 年 10 月）に発表したものに加筆し，まとめたものである。

* 鹿児島大学 教授・工博

** 九州芸術工科大学 助手・工修 (昭和 59 年 12 月 27 日原稿受理)

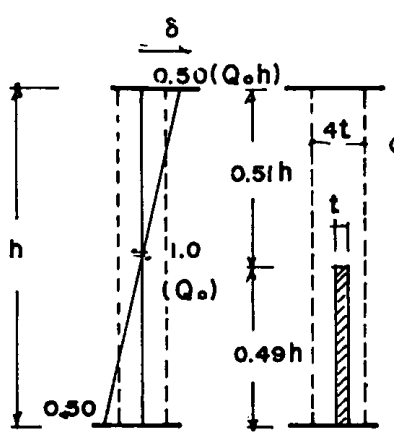

(a)

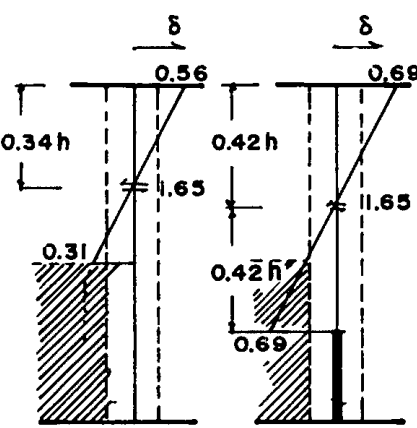

(b) (c)
図一1 光弾性実験から求めた水平力分担割合および反曲点位置 (a)（b）亡㓮域を求めた後の反曲点位置（c）（文献 6) から一部転載)

“剛域の概念の導入は実用上変形計算には簡便な方法 であるが応力計算には必らずしも適していない”ことか ら本稿は，種々な壁厚，高さのたれ壁，腰壁付柱のせん 断力分担割合および反曲点位置に関する光弾性実験に基

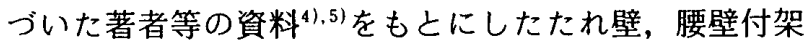
構の一応力計算法を提案しようとするものである。

2. た九壁, 腰壁付柱のせん断力分担割合および反曲 点高さ

2.1 形状の等しいたれ壁, 腰壁付柱のせん断力分担 割合

独立柱の負担せん断力 $Q_{0}$ を基準とした時の形状の等 しい（厚さ, 高さがそれぞれ等しい）たれ壁, 腰壁付柱 のせん断力分担割 $Q / Q_{0}$ が 3 次元モデルの光弾性実験に より壁厚比 $b / t$ ( $b$ : 柱厚， $t$ : 壁厚）および開口高さ 比 $h_{0} / h, h_{0} / D\left(h_{0}\right.$ : 開口高さ, $h:$ 柱高さ, $D:$ 柱幅 $)$ をパラメーターとして両側にたれ壁，腰壁付の場合を図 $-2 \mathrm{a}$ に，片側にたれ壁，腰壁付の場合を図一 $2 \mathrm{~b}$ のよう に求められている5!。図一2a，2bには次のｉ） ii） iii） の関係がある。

i）独立柱の負担せん断力 $Q_{0}$ に対する両側たれ壁, 腰壁付柱の壁高さの増加によるせん断力負担割合の増加 量と片側たれ壁, 腰壁付柱の壁高さの増加によるせん断 力負担割合の増加量の比率は, 壁厚と柱厚が等しい場合 図一 $2 \mathrm{c}$ に示すように開口比 $h_{0} / h$ に関係なく 0.69 であ る。この值は, 光弾性実験で用いたエポキシ樹脂板のポ 


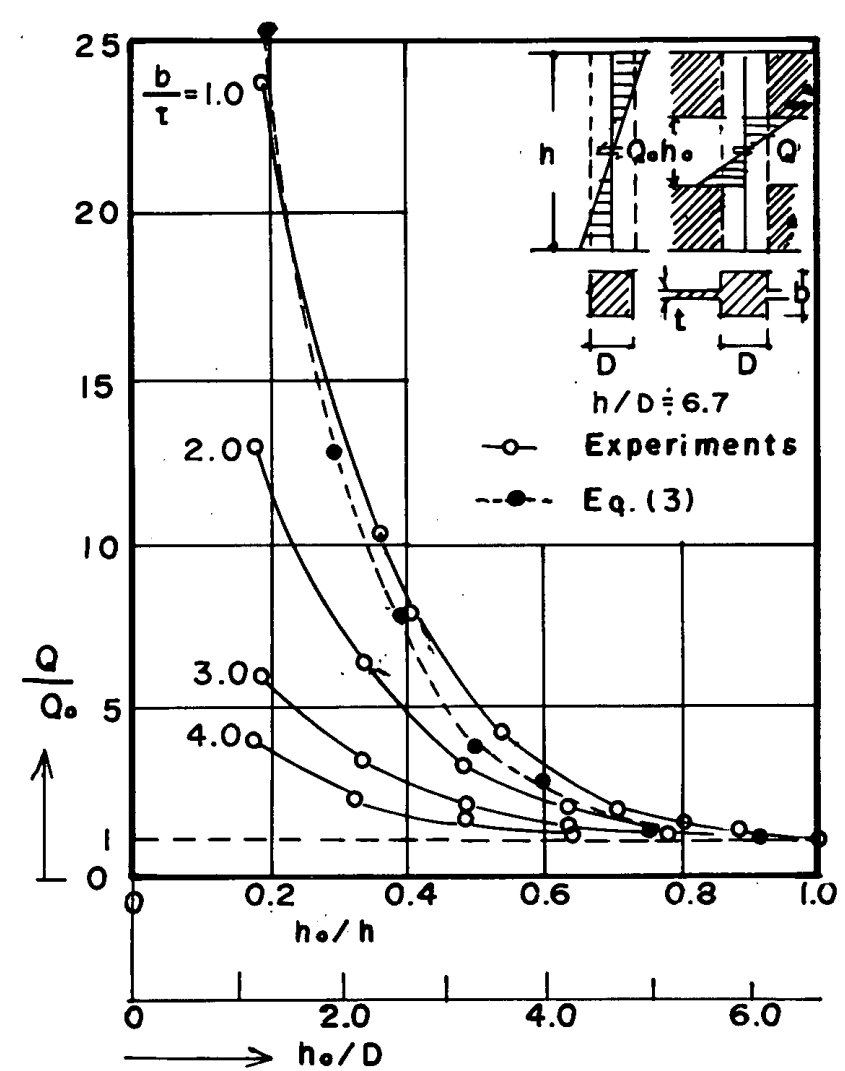

図一2a 両側たれ壁・腰壁付柱と独立柱のせん断力分担割合

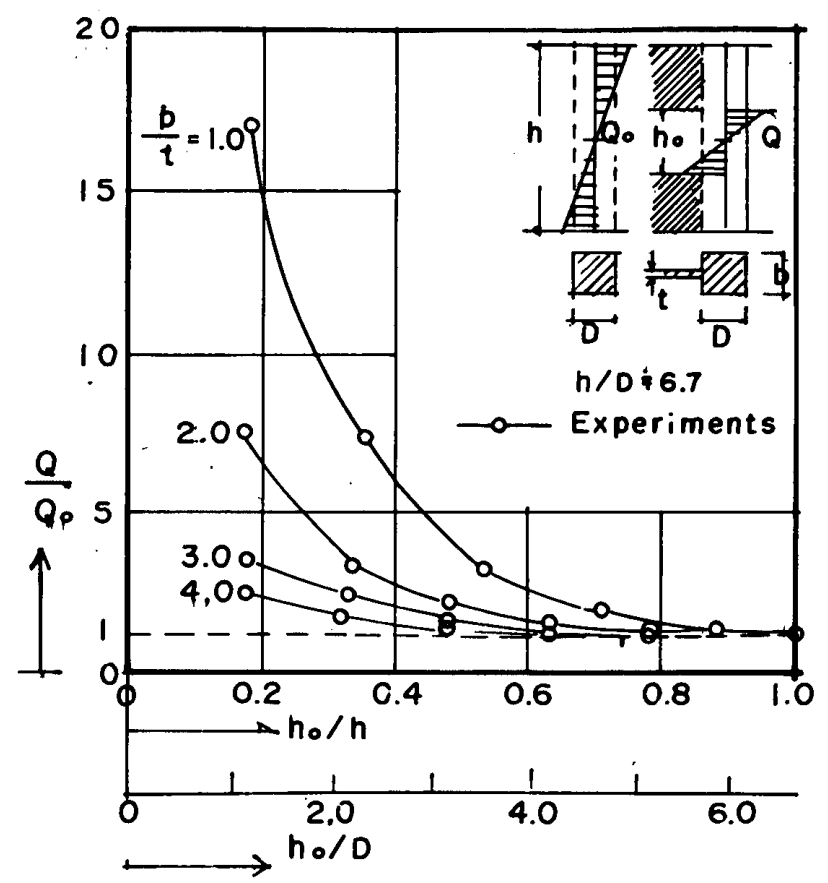

図一2 b 片側たれ壁・腰壁付柱と独立柱のせん断力分担割合

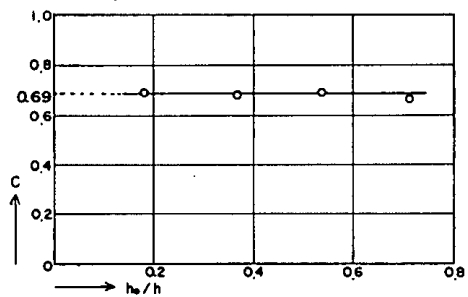

図一2c 壁厚と柱厚が等しい場合の両側たれ壁・腰壁付柱およ び片側たれ壁・腰壁付柱・のそれぞれのせん断力負担 割合增加率の比 $c:(1)$ 式
アソン比の影響が，含まれているが文献 5）で述べてあ る様にエポキシ樹脂板のポアソン比と対象とするコンク リートのポアソン比の差による剛性の差はわずかであ る。

$$
C=\frac{\left[\frac{Q_{(b / t=1.0)}}{Q_{0}}-1.0\right]_{(b)}}{\left[\frac{Q_{(b / t=1.0)}}{Q_{0}}-1.0\right]_{(a)}}=0.69
$$

ここで,

[ ] $]_{(a)}$ 両側たれ壁, 腰壁付柱の壁高さの増加によるせ ん断力負担割合增加量

[ $]_{(b)}$ ：片側たれ壁，腰壁付柱の壁高さの増加によるせ ん断力負担割合の増加量

ii）独立柱の負担せん断力 $Q_{0}$ に対する柱厚に等しい 厚さのたれ壁, 腰壁付柱 $(b / t=1.0)$ の壁高さの増加 によるせん断力負担割合の増加量の比率と柱厚に等しく ないたれ壁, 腰壁付柱 $(b / t \neq 1.0)$ のせん断力負担割 合の増加量の比率は, 図一 3 のように $b / t$ の值にのみ 影響を受け種々の壁高さに対しては一定値となり，壁高 さに関係のない（2a)，(2b) 式および図-4のように なる。

両側にたれ壁, 腰壁付の場合

$$
\phi=\frac{\frac{Q_{(b / t)}}{Q_{0}}-1.0}{\frac{Q_{(b / t=1.0)}}{Q_{0}}-1.0}=e^{-0.68(b / t-1.0)^{1} \cdot 04} \text {. }
$$

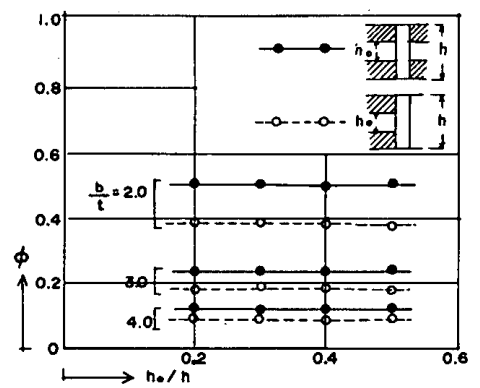

図一-3 開口比 $h_{0} / h$ と $\phi$ の関係

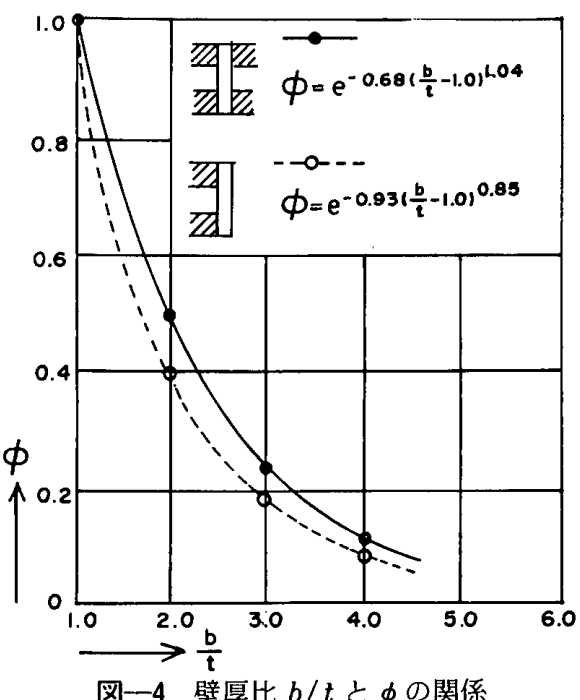


片側たれ壁, 腰壁付の場合

$$
\phi=\frac{\frac{Q_{(b / t)}}{Q_{0}}-1.0}{\frac{Q_{(b / t=1.0)}}{Q_{0}}-1.0}=e^{-0.93(b / t-1.0)^{\circ \cdot 85}}
$$

iii）開口比 $h_{0} / h=0.35\left[h_{0} / D=2.35\right]$ で柱厚に等し い厚さのたれ壁, 腰壁付柱について実験から求めたせん 断力分担割合および壁上端あるいは壁下端から剛域まで の長さを図一5（文献 5）から一部転載）に示す。㓮域 までの長さ $0.23 D$ は規準"1)に示されている㓮域までの 長さ $0.25 D$ とほぼ等しい。ここで独立柱の負担せん断 力 $Q_{0}$ に対して有効可撓長さを $h_{0}+2 \times 0.25 D$ としたと きのたれ壁，腰壁付柱の負担せん断力 $Q$ は，曲げせん 断を考慮したはりの初等理論により求めると（3) 式と なる。

$$
\frac{Q}{Q_{0}}=\frac{\left(\frac{h}{D}\right)\left\{\left(\frac{h}{D}\right)^{2}+2 x(1+\nu)\right\}}{\left(\frac{h_{0}}{D}+0.5\right)\left\{\left(\frac{h_{0}}{D}+0.5\right)^{2}+2 x(1+\nu)\right\}}
$$

ここに,

$$
x=1.2: \text { 形状係数 }
$$

$\nu=0.4:$ 実験に用いたエポキシ板のポアソン比

種々な開口比 $h_{0} / D$ に対して（3）式から求めた結果 を図一2 a 内にの印で示してある。剛域までの長さ $D / 4$ はほぼ壁厚比 $b / t=1.0$ のもとで決められていること から当然のことながら，（3) 式の結果は図一 $2 \mathrm{a}$ 中の

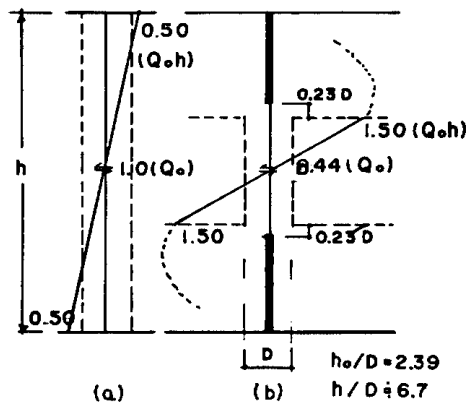

図一5 柱厚に等しいたれ壁・腰壁付柱と独立柱のせん断力負担 割合および剛域までの長さ（文献 5) から一部転載）
$Q_{(b / t=1.0)} / Q_{0}$ に近い。したがって独立柱の負担せん断力 Qに対する壁厚と柱厚が等しい場合のたれ壁，腰壁付 柱のせん断力負担割合 $Q / Q_{0}$ は（3）式で求めた值を用 いることができる。

前述の i） ii） iii）に述べた性質に基づいて，Q/Q は（4）式で示すことができる。

$$
\frac{Q}{Q_{0}}=c \cdot \phi \cdot\left(\frac{Q_{(b / t=1.0)}}{Q_{0}}-1.0\right)+1.0
$$

ここで,

$c, \phi:$ 柱の両側にたれ壁・腰壁が付く場合

$$
\begin{aligned}
& c=1.0 \\
& \phi=e^{-0.68(b / t-1.0)^{1} \cdot a d}
\end{aligned}
$$

：柱の片側にたれ壁・腰壁が付く場合

$$
c=0.69
$$$$
\phi=e^{-0.93(b / t-1.0)^{0} \cdot 95}
$$

$\frac{Q_{(b / t=1.0)}}{Q_{0}}:(3)$ 式による

2.2 形状の異なるたれ壁, 腰壁付柱の反曲点高さ

一般にたれ壁・腰壁付ラーメンのたれ壁, 腰壁の高さ や壁厚は異なっており，また腰壁のみ付いたラーメンの 場合は，はりの一部分がたれ壁に相当すると考えると壁 厚がかなり異なったものとなる。このように形状の異な るたれ壁（はりも含む）・腰壁が付設する柱の反曲点高 さ比 $y$ を求める場合（図一6 a ）, 独立柱の反曲点高さ 比 $y_{0}$ （図一 $6 \mathrm{~b}$ ） に腰壁の影響による反曲点位置の上昇 高さ比 $y_{1}$ (図一6c)，およびたれ壁の影響による反曲 点位置の下降高さ比 $y_{2}$ (図一6 $\mathrm{d}$ ) を（5）式のように 加算する方法で近似する。

$$
y=y_{0}+y_{1}-y_{2}
$$

柱上下端の回転が拘束された腰壁付柱の反曲点高さ比 $y$ が図一7 a，7b (文献 6) から転載) のように実験的に 求められている。同図中の反曲点高さ比 $y$ は腰壁上端 を基点として開口高さ $h_{0}$ に対する比で示されているが, これを柱の中央点すなわち図一 $6(\mathrm{~b})$ の反曲点位置 $y_{0}$ を 基点として（5）式のように表現しなおすと $y_{1} ， y_{2}$ は (6a)，(6b) 式のようになる。

柱の両側にたれ壁, 腰壁が付いた場合,

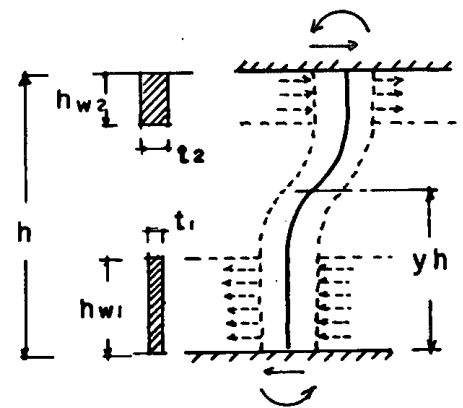

(a)

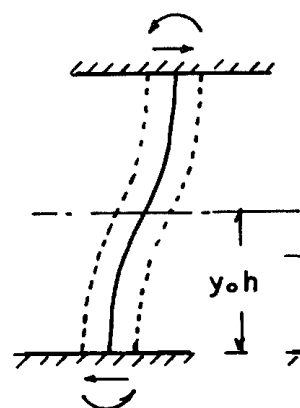

(b)

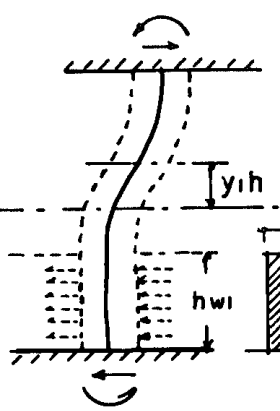

(c)

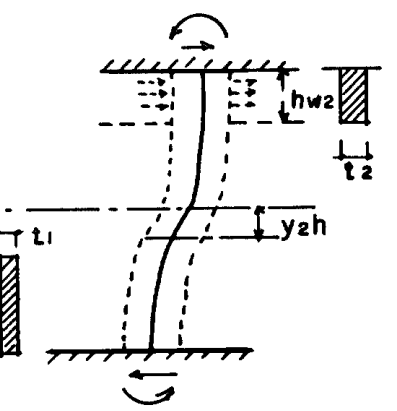

(d)

図一6 形状の異なるたれ壁・腰壁付柱の反曲点位置の近似計算法 


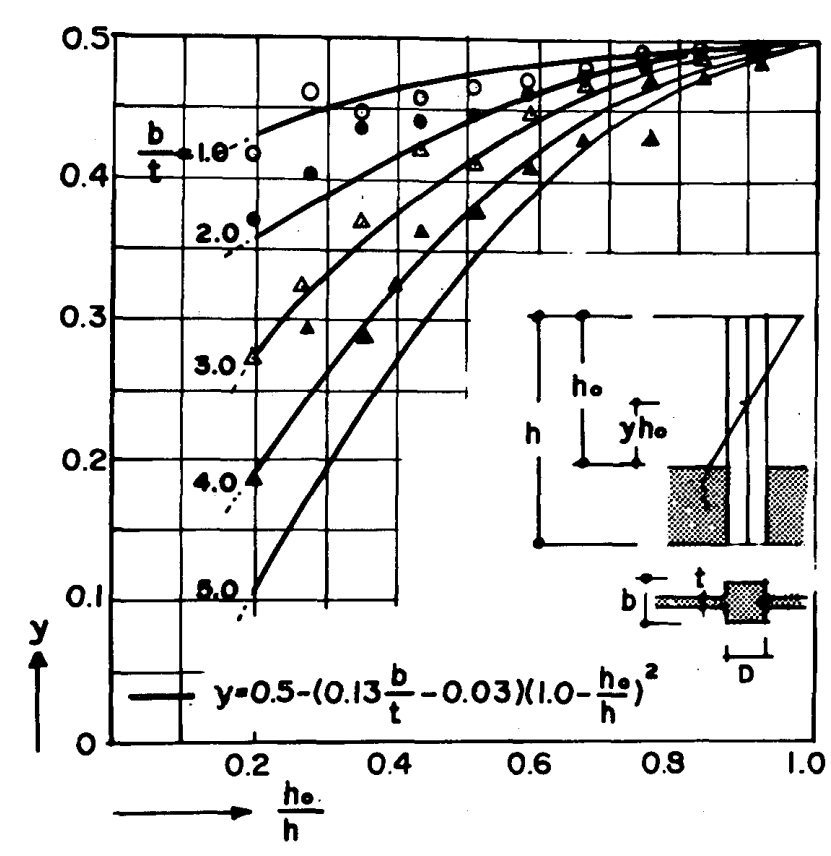

図一7 a 種々な壁厚比 $b / t$ に対する両側腰壁付柱の反曲点高 さ比 $y$

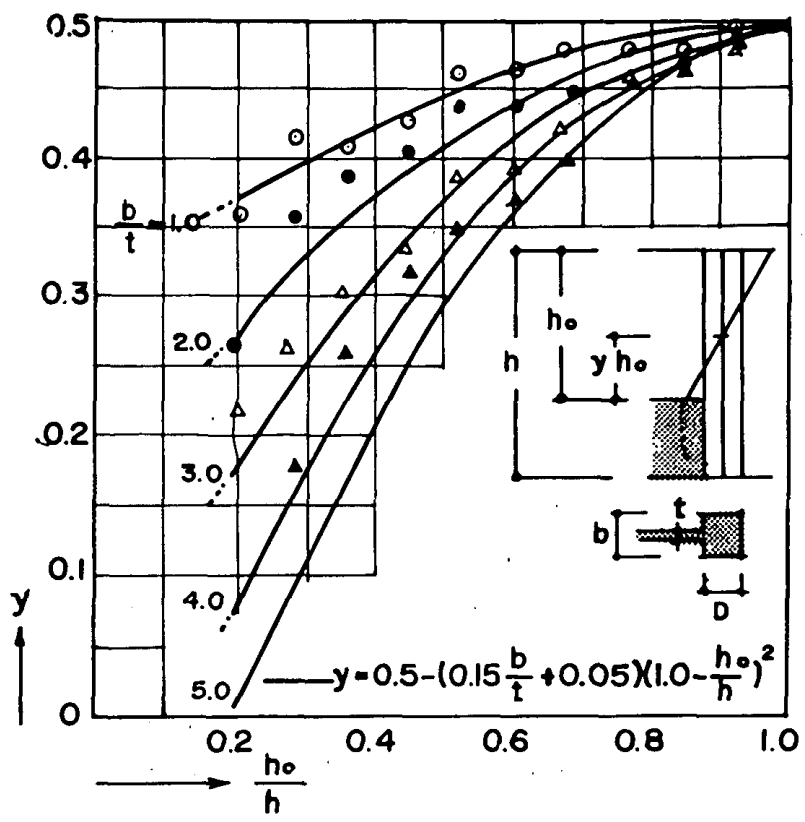

図一7 $\mathrm{b}$ 種々な壁厚比 $b / t$ に対する片側腰壁付柱の反曲点高 さ比 $y$

$$
\begin{aligned}
y_{1}, y_{2}= & \left\{0.5-\left(0.13 \frac{b}{t}-0.03\right)\left(\frac{h_{w}}{h}\right)^{2}\right\}\left(1-\frac{h_{w}}{h}\right) \\
& +\frac{h_{w}}{h}-0.5 \cdots \cdots \cdots \cdots \cdots \cdots \cdots \cdots \cdots \cdots \cdots \cdots \cdots \cdots \cdots \cdots \cdots
\end{aligned}
$$

柱の片側にたれ壁，腰壁が付いた場合

$$
\begin{aligned}
y_{1}, y_{2}= & \left\{0.5-\left(0.15 \frac{b}{t}+0.05\right)\left(\frac{h_{w}}{h}\right)^{2}\right\}\left(1-\frac{h_{w}}{h}\right) \\
& +\frac{h_{w}}{h}-0.5 \cdots \cdots \cdots \cdots \cdots \cdots \cdots \cdots \cdots \cdots \cdots \cdots \cdots \cdots \cdots \cdots \cdots \cdots
\end{aligned}
$$

上式において, $y_{1}$ 計算時の $t, h_{w}$ は腰壁の厚さ $t_{1}$, 高さ $h_{w 1}$ を用い, $y_{2}$ 計算時の $t, h_{w}$ はたれ壁の厚さ $t_{2}$,
高さ $h_{w 2}$ を用いる。

2.3 形状の異なるたれ壁, 腰壁付柱のせん断力負担 割合

形状の異なるたれ壁，腰壁が付設する柱（図一8a） の負担せん断力を求める場合，前節（2.2）で求めた反 曲点高さ $y \cdot h$ と以下の i ) ii ) の手順を用いる。

i）高さ $2 y \cdot h$ で腰壁と等しいたれ壁が付設された 柱,すなわち中央水平線に対して対称な形状の壁付柱(図 -8b）の同じ高さの独立柱の負担せん断力 $Q_{0 b}$ に対す るせん断力負担割合 $Q_{b} / Q_{0} b$ を (4) 式で求める。

ii）高さ $2(1-y) \cdot h$ でたれ壁と等しい腰壁が付設さ れた柱，すなわち中央水平線に対して対称な形状の壁付 柱（図一8c）の同じ高さの独立柱の負担せん断力 $Q_{0 c}$ に対するせん断力負担割合 $Q_{c} / Q_{0 c}$ を(4) 式で求める。

図一8において, 水平変位 $\delta_{a}, \delta_{b}, \delta_{c}$ は, はりの初

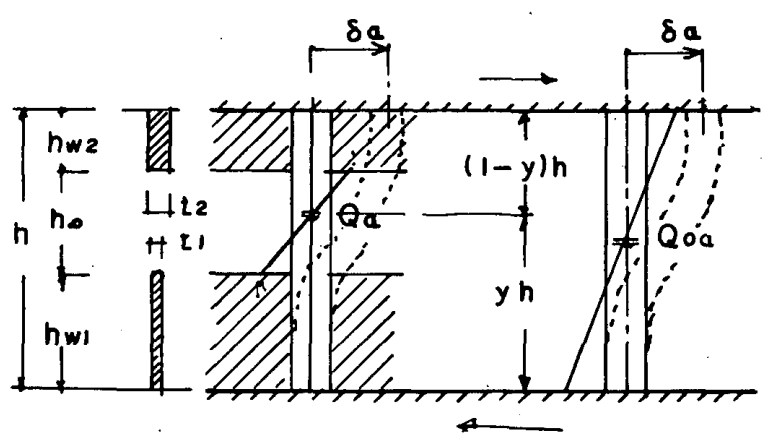

図一8 a 材長 $h$ で形状の異なるたれ壁腰付柱の反曲点位置とせ 几断力 $Q_{a}$

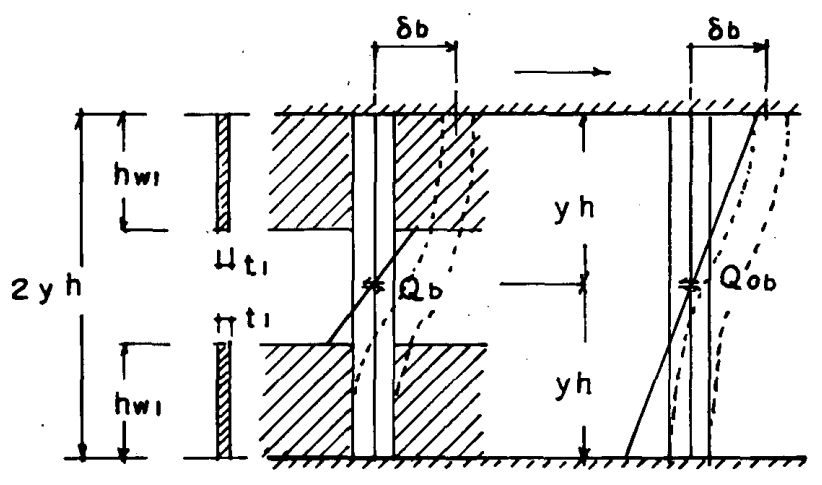

図一8 b 材長 $2 y h$ で形状の等しいたれ壁・腰壁付柱の独立柱 に対するせん断力 $Q_{0}$

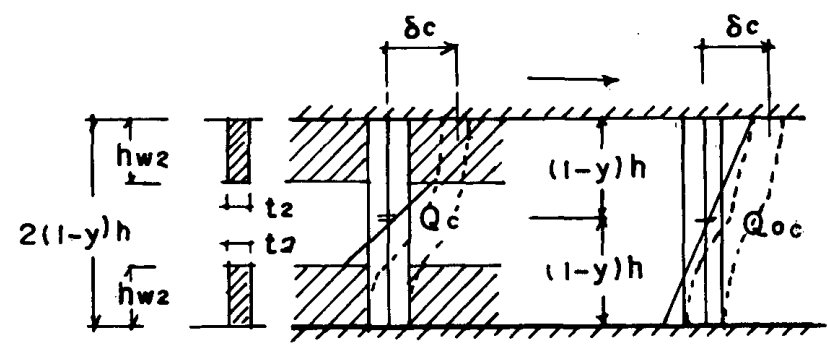

図一8c 材長 $2(1-y) h$ で形状の等しいたれ壁・腰壁付柱の独立 柱に対するせん断力 $Q_{c}$ 
等理論により（7)，（8），（9）式となり, 形状の異な るたれ壁, 腰壁が付設する柱の負担せん断力 $Q_{a}$ が $Q_{b}$, $Q_{c}$ に等しい場合 $\left(Q_{a}=Q_{b}=Q_{c}\right)(10)$ 式が成立する。

$$
\begin{aligned}
& \delta_{a}=\left(\frac{h^{3}}{12 E I}+\frac{x h}{G A}\right) \cdot Q_{0 a} \\
& \frac{\delta_{b}}{2}=\left(\frac{(y h)^{3}}{3 E I}+\frac{x y h}{G A}\right) \cdot Q_{0 b} \\
& \frac{\delta_{c}}{2}=\left[\frac{\{(1-y) \cdot h\}^{3}}{3 E I}+\frac{x_{\{}\{(1-y) \cdot h\}}{G A}\right] \cdot Q_{o c} \\
& \delta_{a}=\frac{\delta_{b}+\delta_{c}}{2}
\end{aligned}
$$

ここで,

$$
\begin{aligned}
I & =b D^{3} / 12: \text { 断面二次モーメント } \\
G & =E /[2(1+\nu)]: \text { せん断弾性係数 } \\
A & =b \cdot D: \text { 断面積 } \\
x & =1,2: \text { 形状係数 }
\end{aligned}
$$

（7）（10）式および形状の等しいたれ壁，腰壁付柱 の独立柱に対するせん断力負担割合 $Q_{b} / Q_{0 b}, Q_{c} / Q_{0 c}$ の 式から形状の異なるたれ壁, 腰壁付柱の独立柱に対する せん断力負担割合は（11）式となる。

$$
\frac{Q_{a}}{Q_{0 a}}=\frac{1}{\psi_{1} / \frac{Q_{b}}{Q_{0 b}}+\psi_{2} / \frac{Q_{c}}{Q_{0 c}}}
$$

ここで

$$
\begin{aligned}
& \psi_{1}=\frac{4 y^{3} \cdot\left(\frac{h}{D}\right)^{2}+2.4(1+\nu) \cdot y}{\left(\frac{h}{D}\right)^{2}+2.4(1+\nu)} \\
& \psi_{2}=\frac{4(1-y)^{3} \cdot\left(\frac{h}{D}\right)^{2}+2.4(1+\nu) \cdot(1-y)}{\left(\frac{h}{D}\right)^{2}+2.4(1+\nu)}
\end{aligned}
$$

\section{3. たれ壁, 腰壁付架構の応力計算}

本計算法は，従来多く用いられている剛域を仮定した 架構の計算法と異なり，2.で示したようにたれ壁，腰 壁が付かない架構を基準として,たれ壁, 腰壁が付くこ とによる影響を考慮する方法による。

以下に応力計算の手順を示し，その計算法が実用に供 し得ることを確めるため腰壁付 3 層 3 スパンの架構に等 分布水平力を加える光弾性実験を行い比較を行った。

\section{1 応力計算法}

¡）はり・柱接合部は判接点（㴊域を考虑しない）の 純ラーメンとして反曲点位置を求める。ただし，はりに ついてはたれ壁，腰壁を考虑した断面を用い，その重心 線をラーメン線とする（図一9）。

ii）たれ壁，腰壁付柱の反曲点高さ比 $y$ は，i）で 求めた反曲点高さ比を $y_{0}$ とし腰壁に関する修正項 $y_{1}$ お よびたれ壁に関する修正項 $y_{2}$ とにより（5）式で表す。

$$
y=y_{0}+y_{1}-y_{2}
$$

$y_{1}, y_{2}$ の計算に用いられる $(6 \mathrm{a})(6 \mathrm{~b})$ 式ので,

$h:$ 上下壁付はりの重心間距離

$h_{w}$ :腰壁 (たれ壁) のはり重心からの高さ

$b:$ 柱厚

$t:$ 腰壁（たれ壁）の厚さ，ただしたれ壁がない場 合ははり幅

iii）架構のたれ壁，腰壁付柱の負担せん断力 $Q_{F}$ 之， 壁が付設されてない架構の柱の負担せん断力 $Q_{O F}$ の比は

(11) 式で求められる水平力分担割合 $Q_{a} / Q_{0 a}$ に節点の 回転を考慮し以下の修正を $D$ 值法 ${ }^{1}$ に従って行う。

$$
\frac{Q_{F}}{Q_{0 F}}=\frac{a}{a_{0}} \frac{Q_{a}}{Q_{0 a}}
$$

一般層

$$
a, a_{0}=\frac{\bar{k}}{2+\bar{k}}, \bar{k}=\frac{\sum k_{b}}{2 \alpha k_{c}}
$$

最下層

$$
a, a_{0}=\frac{0.5+\bar{k}}{2+\bar{k}}, \bar{k}=\frac{\sum k_{b}}{a k_{c}}
$$

$k_{b}: a_{0}$ 計算時は, たれ壁, 腰壁が付いていないは りの剛比, $a$ 計算時は, たれ壁, 腰壁を考慮し たはりの剛比

$k_{c}$ ：たれ壁，腰壁を考慮しない柱材長 $h$ の㓮比

$\alpha: a_{0}$ 計算時は, $\alpha=1.0, \alpha$ 計算時はたれ壁, 腰 壁が付設されることによる剛性増加率で (11) 式の水平力負担割合 $Q_{a} / Q_{0 a}$ を用いる。

iv）はりの曲げモーメントは，各節点ごとにその上下 の柱端から伝わるモーメントを左右のはりの剛比に比例 分割して求める。

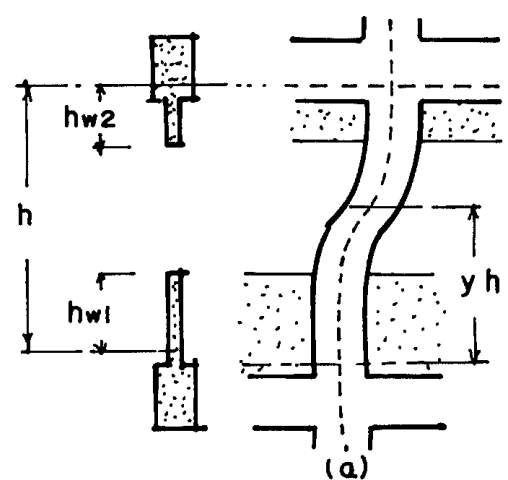

(a)

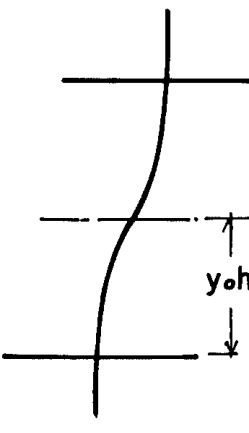

(b)

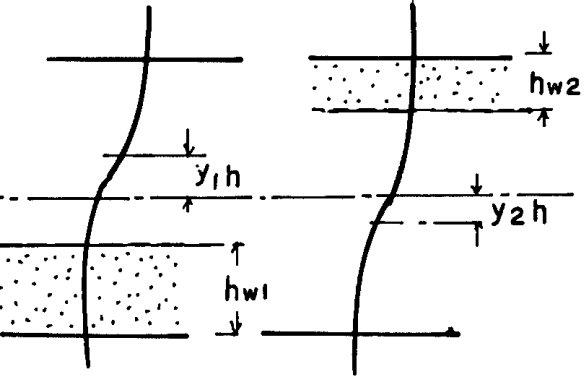

(c) (d)

図一9形状の異なるたれ壁・腰壁付架構のラーメン線（鎖線）と反曲点位置 
3.2 腰壁付架構の光弾性実験結果と本計算法による 結果との比較

一枚のエポキシ樹脂板（厚さ $9 \mathrm{~mm}$ ) から柱, はり部 分を作製し, 厚さ $2 \mathrm{~mm}$ の腰壁をラーメン内に接着した。 腰壁高さを変化させ，等分布水平力を加え光弾性撮影 を行った。実験より得られた等色線写真のうち, 腰壁が 低い場合と高い場合を写真一1 a，1bに示す。

等色線写真より得られた各層の内柱と外柱の水平力分 担割合および反曲点高さ比 $y$ を図一 $10 \mathrm{a}, 10 \mathrm{~b}$ の実験值 の欄（exp.）に示す。ただし，実験では左右の柱の反 曲点位置およびせん断力は軸力の影響により差が生じた が，平均值を示してある。同試験体に本計算法を適用し た結果は図一10 a, $10 \mathrm{~b}$ の計算値の欄（cal.）に示す。

なお 3.1 の）の純ラーメンの応力計算は, 曲げ変形, せん断変形を考慮した（剛域を考虑しない） $D$ 值法に より, 反曲点高さ比は腰壁が付かないはりの重心線を基 準として示してある。実験における加力点は，はりの中 心線上で腰壁を考虑した重心線（計算に用いたラーメン

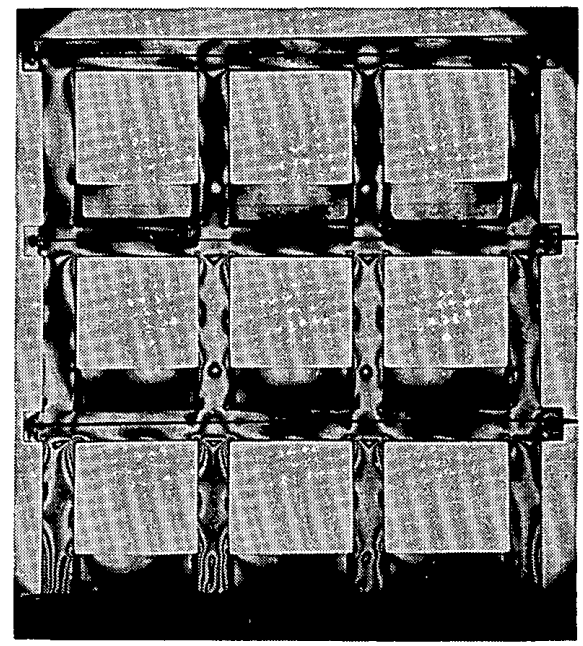

写真一1 腰壁付架構の光弾性実験写真 (腰壁が低い場合, 壁厚 比 $b / t=4.5$, 暗視野)

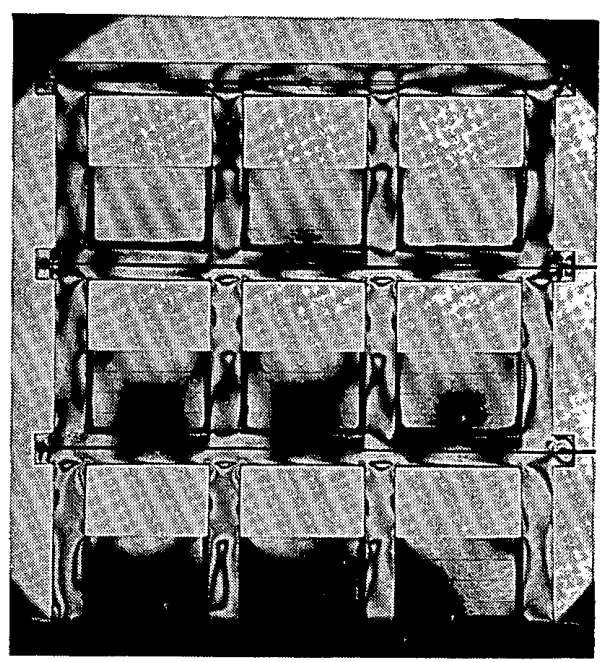

写真一2 腰壁付架構の光弾性実験写真 (腰壁が高い場合, 壁厚 比 $b / t=4.5$, 暗視野)
線）と異なり，厳密な意味での比較とならないが，実験 値と計算值の差はわずかである。以上のように 2 種類の 腰壁高さ $h_{w} / h^{\prime}=0.267,0.533\left(h_{w}\right.$ : 腰壁高さ, $h^{\prime}$ : はり内のり間距離）の架構の計算結果を示した。さらに 腰壁高さの変化による反曲点位置の変化を内柱（柱の両 側に腰壁が付設）について図一11 a に，外柱（柱の片側 に腰壁が付設) について図一11 b に示した。

また同図内に，はり・柱接合パネル部の回転が拘束さ れた (固定) 状態の場合の反曲点位置の変化を $\Delta$ 印で示 した。腰壁高さが $h_{w} / h^{\prime} \geqq 0.26$ の場合，腰壁による柱 脚回転の拘束が大きく、柱頭・柱脚を固定して計算した 結果と差がない。この場合 $\left(h_{w} / h^{\prime}=0.26\right)$ の腰壁付は

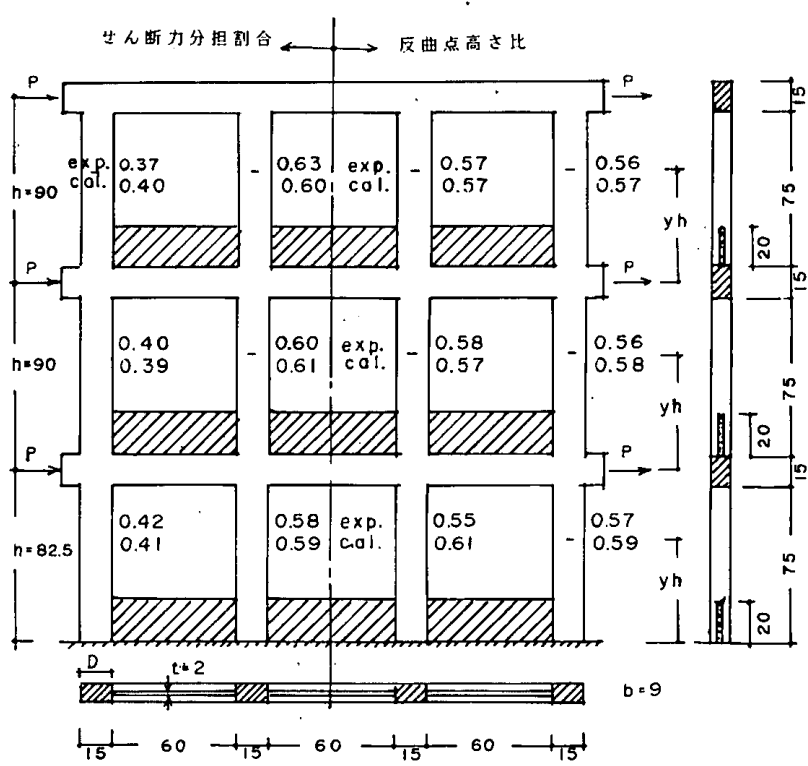

図一10a 低い腰壁付架構の内柱・外柱のせん断力分担割合お よび反曲点高さ比の実験値と計算値の比較（上段： 実験値，下段：計算値，寸法単位：mm)

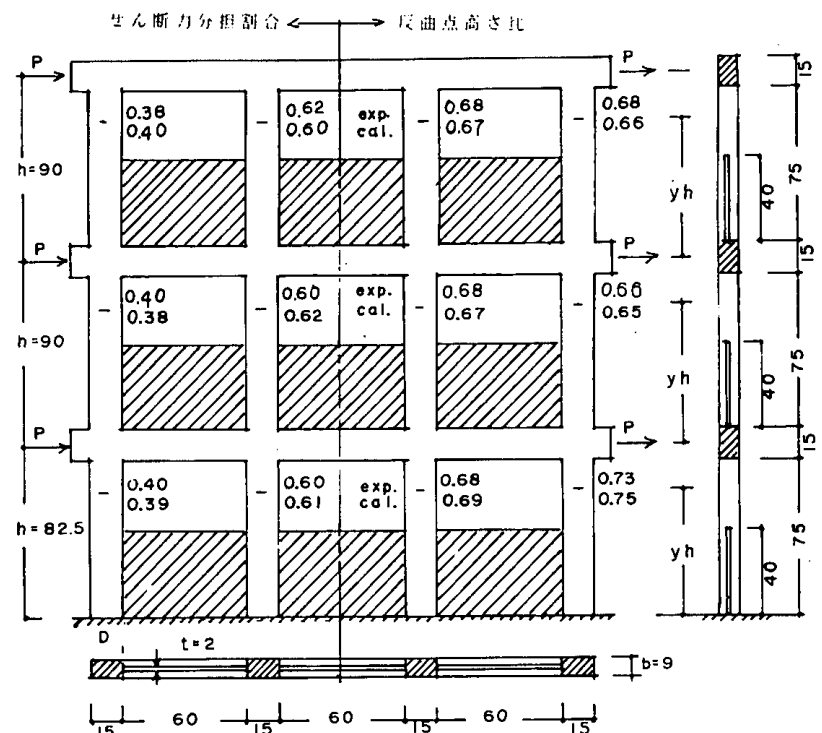

図一10b 高い腰壁付架構の内柱・外柱のせん断力分担割合お よび反曲点高さ比の実験値と計算値の比較（上段： 実験値，下段：計算値，寸法単位：mm) 

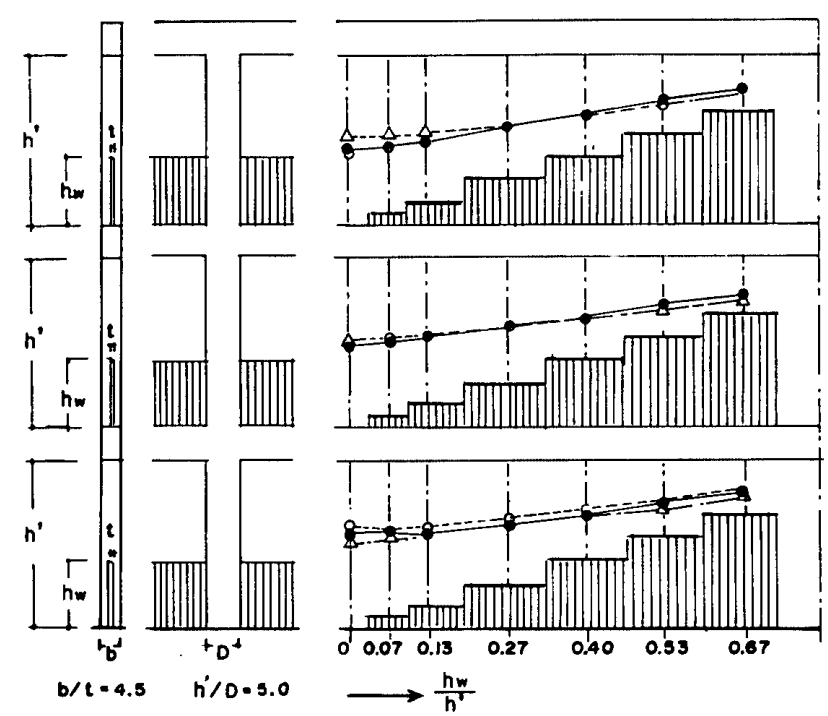

図一11 a 両側に腰壁付柱の腰壁高さの変化による反曲点位置 の変化

実験值，○3.1 の計算法による値

$\triangle$ 柱頭・柱脚を固定として計算した値

りを凸断面，柱を長方形断面としてそれらの剛性比を求 めると 5.79 となる。

$$
\frac{I_{b} \times h}{I_{c} \times l}=5.79
$$

$I_{b}:$ 腰壁付はりの断面二次モーメント

$I_{c}:$ 柱の断面二次モーメント

$h:$ 階高, $l:$ スパン

(12）式がおよそ6以上あるときの腰壁付架構の応力 計算は柱・はり接点を固定端として行ってもよいことに なる。

\section{4. むすび}

たれ壁, 腰壁付架構の応力計算には，剛域の概念を導 入した解析法が一般に用いられている。しかし，㴊域を 仮定して求めた応力と実際の応力とは異なることから, 本研究では剛域の概念を導入せず，既往の光弾性実験資 料をもとに応力計算する一方法を提案した。この方法に よる計算と応力を求める実験（光弾性実験）との対応は

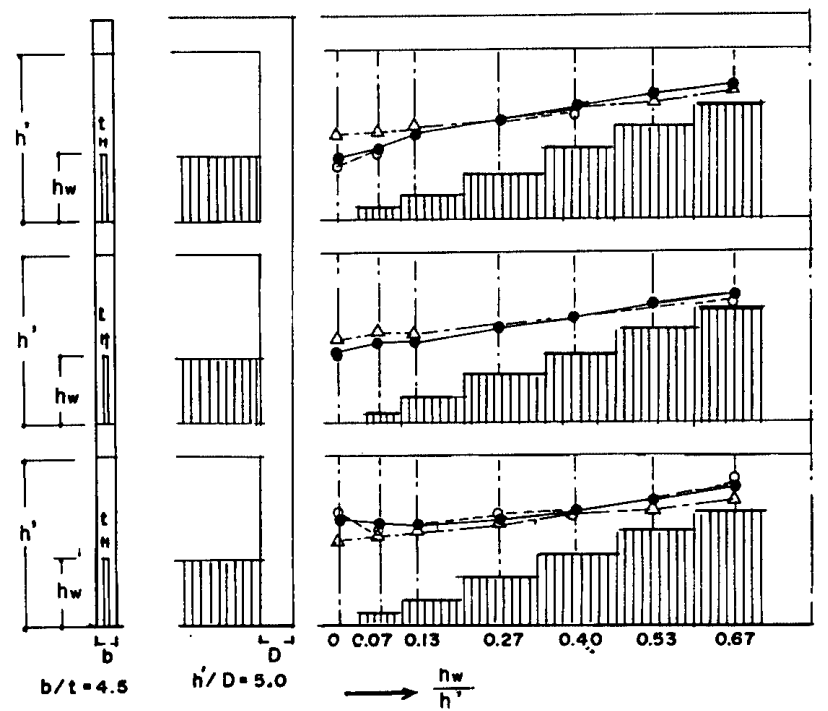

図一11 b 片側に腰壁付柱の腰壁高さの変化による反曲点位置 の変化

実験値，○3.1の計算法による値 $\triangle$ 柱頭・柱脚を固定として計算した値

非常に良好であった。

\section{謝 辞}

本研究をまとめるにあたり，鹿児島大学助手・久徳琢 磨氏, 同大学院生・松田純治, 古賀 醇の各氏の協力を 頂きました。ここに謝意を表します。

\section{引用文献}

1) 日本建築学会：鉄筋コンクリート構造計算規準, 同解説, 1982

2) 日本建築センター：構造計算指針, 同解説

3）武藤 清: 耐震設計シリーズ I, 耐震設計法, 丸善

4）大久保全陸：腰壁，たれ壁，そで壁付き鉄筋コンクリー 卜骨組の剛性, 強度および履歴特性に関する研究, 日本 建築学会論文報告集, 86 号, 昭和 46 年 8 月

5）徳広育夫・佐々木昭夫：たれ壁, 腰壁付柱の弾性剛性に 関する研究 (I) 日本建築学会論文報告集, 第 304 号, 昭和 56 年 6 月

6) 徳広育夫 ·久徳琢磨：たれ壁, 腰壁付柱の弾性用性に関 する研究（II）日本建築学会論文報告集, 第 318 号, 昭 和 57 年 8 月 


\section{SYNOPSIS}

UDC : 624. 075. $2: 69.022 .1$

A METHOD OF STRESS CALCULATION OF FRAME WITH SPANDREL WALL

- Studies on elastic rigidities of columns with spandrel wall (III)-

by Dr. IKUO TOKUHIRO, Professor of Kagoshima University, and SHINICHI SHIOYA, Research assistant of Kyushu Institute of Design, Members of A. I. J.

Up to now, a frame with spandrel wall such as deep beam has been calculated by assuming the rigid zones in columns. But this method is not always accurate in taking account in stresses. Accordingly, in this paper a stress calculation method of frame with spandrel walls without assuming rigid zone is shown, and it is presented that the results by the proposed method fairly agree with the photo-elastic experimental results. 